This document is confidential and is proprietary to the American Chemical Society and its authors. Do not copy or disclose without written permission. If you have received this item in error, notify the sender and delete all copies.

\title{
Culture-independent analysis of linuron mineralizing microbiota and functions in on-farm biopurification systems via DNA-Stable Isotope Probing: comparison with enrichment culture
}

\begin{tabular}{|c|c|}
\hline Journal: & Environmental Science \& Technology \\
\hline Manuscript ID & es-2019-05583x \\
\hline Manuscript Type: & Article \\
\hline $\begin{array}{r}\text { Date Submitted by the } \\
\text { Author: }\end{array}$ & 16-Sep-2019 \\
\hline Complete List of Authors: & $\begin{array}{l}\text { Lerner, Harry; KU Leuven, Division of Soil and Water Management } \\
\text { Öztürk, Basak; KU Leuven, Division of Soil and Water management; } \\
\text { Leibniz Institute German Collection of Microorganisms and Cell Cultures, } \\
\text { Junior Research Group Microbial Biotechnology } \\
\text { Dohrmann, Anja; Johann Heinrich von Thünen-Institut Federal Research } \\
\text { Institute for Rural Areas Forestry and Fisheries, Thünen Institute of } \\
\text { Biodiversity } \\
\text { Thomas, Joice; KU Leuven, Molecular Design and Synthesis } \\
\text { Marchal, Kathleen; Ghent University, Department of Plant Biotechnology } \\
\text { and Bioinformatics } \\
\text { De Mot, René; KU Leuven, Centre of Microbial and Plant Genetics } \\
\text { Dehaen, Wim; KU Leuven, Molecular Design and Synthesis } \\
\text { Tebbe, Christoph; Johann Heinrich von Thünen-Institut Federal Research } \\
\text { Institute for Rural Areas Forestry and Fisheries, Thünen Institute of } \\
\text { Biodiversity } \\
\text { Springael, Dirk; KU Leuven, Division of Soil and Water Management }\end{array}$ \\
\hline
\end{tabular}

\section{SCHOLARONE Manuscripts}


1 Culture-independent analysis of linuron mineralizing microbiota and 2 functions in on-farm biopurification systems via DNA-Stable Isotope

\section{Probing: comparison with enrichment culture}

4

11 ‡Current address: Junior Research Group Microbial Biotechnology;

12 Leibniz Institute DSMZ, German collection of microorganisms and cell cultures 
Our understanding of the microbiota involved in in situ biodegradation of xenobiotics like pesticides in natural and engineered environments is poor, taking into account the large fraction of uncultivables. Onfarm biopurification systems (BPSs) treating farm-produced pesticide-contaminated waste water are interesting environments to study microbial community adaptation. DNA-stable isotope probing (DNASIP) identified Ramlibacter and Variovorax as the main in situ assimilators of the phenylurea herbicide

21 linuron in the BPS matrix. While Variovorax strains are common linuron-degrading isolates, Ramlibacter

22 was never before implicated in linuron degradation. Known catabolic genes for linuron hydrolysis and 23 aromatic ring conversion were enriched in the ${ }^{13} \mathrm{C}$-DNA fractions, as well as mobile genetic elements

24 previously linked to linuron catabolic genes, suggesting that in situ linuron assimilation related to 25 known catabolic modules which are prone to horizontal gene transfer. Soil free culturing of linuron degraders from the BPS sample resulted in a community dominated by Variovorax while Ramlibacter was not recovered. Our work provides evidence for the role of the common linuron degrading isolate Variovorax in in situ linuron biodegradation but also shows that culturing only provides a partial picture of the in situ linuron degrading microbiota in the BPS environment.

\section{INTRODUCTION}

32 The toxic properties of pesticides often extend beyond their intended targets and impose a major

33 environmental and health concern. Point source contamination, i.e., the uncontrolled release of 34 pesticides at high concentrations, often originates at the farm yard during the cleaning and filling of 35 spraying equipment ${ }^{1}$. On-farm biopurification systems (BPSs), consisting of an excavation or container 36 that contains a matrix composed of soil, lignocellulosic material and humified organic substrate such as 37 peat, treat pesticide contaminated wastewater at farm yards through biodegradation and sorption ${ }^{1-4}$. 
Besides their application in water treatment, BPSs are considered interesting environments for studying genetic adaptation to pesticides and organic xenobiotics. They are operated on a long-term and continuous base with high pesticide loads, thereby imposing a strong selective pressure for the evolution and proliferation of pesticide degrading bacteria ${ }^{5,6}$. A well-studied pesticide in the context of the bacterial ecology of xenobiotic biodegradation, is the phenylurea herbicide linuron $(3-(3,4-$ dichlorophenyl)-1-methoxy-1-methyl urea)7 . Culture-dependent studies, mainly targeting agricultural soil, indicate that biodegradation is performed by either individual bacterial strains or consortia. Strains of the genus Variovorax seem to play a crucial role by either performing the complete mineralization, or by performing at least the initial hydrolysis step in consortia ${ }^{8-11}$. Various genes involved in linuron catabolism have been identified. $l i b A^{12}$ and $h y / A^{13}$, identified in Variovorax, encode for enzymes that hydrolyze linuron to 3,4-dichloroaniline (DCA), while dcaQTA1A2BR and $c c d R C F D E$ encode for the conversion of DCA to chlorocatechol and of chlorocatechol to oxoadipate, respectively. These catabolic functions are often located on mobile genetic elements, indicating that horizontal gene transfer contributes to their evolution and dissemination ${ }^{14,15}$. Initial studies using targeted qPCR approaches,

52 indicated that Variovorax and the above mentioned catabolic genes are also relevant for linuron degradation in BPS. However, these studies intentionally used agricultural soil inhabited by linuron

54 degrading Variovorax strains as an ingredient of an artificial BPS matrix to assess bioaugmentation with

55 linuron acclimated materials ${ }^{16-19}$. Recent studies on an operational BPS environment showed that

56 Variovorax associated linuron catabolic genes are present on mobile genetic elements (MGEs) ${ }^{6,20}$ but

57 their indigenous hosts remain elusive.

58 While various pesticide degrading isolates have been reported, knowledge about the microbiota

59 responsible for in situ pesticide degradation is scarce and the contribution of isolates to the in situ process is not clear. Stable Isotope Probing (SIP) and in particular Nucleic acid based Stable Isotope

61 Probing (RNA/DNA-SIP) holds a great promise to culture-independently link identity with in situ 
62 functionality in complex communities and reveal uncultivated micro-organisms and the catabolic

63 functions that govern biodegradation in natural and engineered habitats ${ }^{21-23}$. Only few studies identified

64 in situ degraders of pesticides using SIP and none of those have taken into account functionality.

65 Moreover, most studies examined agricultural soil, but the engineered environment of a bioremediation

66 system, and in particular the complex BPS environment, have yet to be scrutinized. In addition, only few

67 pesticide compounds were targeted and none of them belong to the environmentally important group

68 of phenylurea herbicides ${ }^{23}$.

69 In this study, DNA-SIP combined with 16S rRNA gene amplicon sequencing was used to identify in situ

70 degraders of linuron in the complex environment of a BPS material with a history of linuron exposure, in

71 a microcosm setup. In addition to 16S rRNA gene amplicon sequencing, PCR targeting known linuron

72 catabolic genes as well as genes for MGEs, was used to assess their implication in in situ linuron

73 biodegradation. Two time points were considered, spanning a period of 440 days, to determine

74 robustness. Moreover, to examine whether DNA-SIP and culturing identified the same linuron catabolic

75 organisms and gene functions, and hence to estimate the effect of culturing bias, an enrichment culture

76 (EC) derived from the BPS material was likewise examined regarding community composition and

77 functionality.

78

79 MATERIALS AND METHODS.

80 Chemicals used. Linuron [3-(3,4-dichlorophenyl)-1-methoxy-1-methyl urea] (purity, 99.5\%) was

81 purchased from Sigma Aldrich (St. Louis, MO) and ${ }^{14} \mathrm{C}$ linuron ([phenyl-U-14C]-linuron) (16.93 mCi/mM,

82 radiochemical purity $>95 \%$ ) from Izotop (Hungary). ${ }^{13} \mathrm{C}$ linuron ([phenyl-U-13C] linuron) was synthesized

83 in house based on a protocol modified from ${ }^{24}$. The procedure of in-house synthesis is provided in the

84 supporting material. 
Microcosm setup. Microcosms were set up in glass cylinders of $4 \mathrm{~cm}$ diameter and $10 \mathrm{~cm}$ height and equipped with glass filters as described ${ }^{25}$. The cylinders were filled to a height of $7 \mathrm{~cm}$ with sieved (2 $\mathrm{mm}$ ) BPS matrix material. The BPS material originated from a BPS installed in 2013 at the Inagro agricultural research center (Kortrijk, Belgium) and was composed of 50\% (v/v) coconut husks, 40\% (v/v) potting soil and $10 \%(\mathrm{v} / \mathrm{v})$ agricultural soil. Prior to sampling, the BPS received wastewater contaminated with a pesticide mixture that included linuron, for 2 years. The list of pesticides used at Inagro during that period is provided in the supporting material. Around $2 \mathrm{~kg}$ BPS matrix was collected in October 2015 from the upper $10 \mathrm{~cm}$ layer of matrix in the top container of the system, at positions where the wastewater was distributed over the matrix surface. Samples were mixed and used in the set up of triplicate microcosms for two treatments. The first treatment consisted of an irregular irrigation (three times per week) with $1 \mathrm{~mL}$ of sterile water containing $20 \mathrm{mg} \mathrm{L}^{-1}$ linuron (BPS ${ }^{+}$) while in the second treatment the microcosms were irrigated with $1 \mathrm{~mL}$ of sterile water without linuron (BPS-). The microcosms were incubated at $25^{\circ} \mathrm{C}$ in the dark.

DNA-SIP analysis. DNA-SIP experiments were set up in $20 \mathrm{~mL}$ pyrex glass-tubes containing material from the microcosms taken after 180 days (SIP-1) and 440 days (SIP-2) of treatment. SIP-1 was set up by spiking 0.5 gram of material taken from one $\mathrm{BPS}^{+}$and one BPS ${ }^{-}$microcosm, with $0.5 \mathrm{ml} \mathrm{MS} \mathrm{medium}{ }^{26}$ containing either $100 \mathrm{mg} \mathrm{L}^{-1}$ of ${ }^{13} \mathrm{C}$-ring labeled linuron or $100 \mathrm{mg} \mathrm{L}^{-1}$ non-labeled linuron, in addition to $11.65 \mathrm{\mu g} \mathrm{l}^{-1}\left(\sim 80 \mathrm{bq} \mathrm{ml}^{-1}\right){ }^{14} \mathrm{C}$ ring-labeled linuron. The vials were incubated at $20^{\circ} \mathrm{C}$ on a rotary shaker at $120 \mathrm{rpm}$ in the dark. The vials were equipped with $\mathrm{CO}_{2}$-traps that were sampled regularly and the radioactivity was determined to generate cumulative mineralization curves as reported ${ }^{27}$. Six and three 105 replicates were initiated using BPS $^{+}$and BPS material, respectively. Assay vials without microcosm 106 material were included as negative controls for mineralization. 
SIP-2 was set up identically to SIP-1, except that the used material consisted of pooled material from all $\mathrm{BPS}^{+}$or BPS- microcosms and that no ${ }^{14} \mathrm{C}$ ring-labeled linuron was spiked. Instead, an identically ${ }^{14} \mathrm{C}-$ ring labeled linuron mineralization-assay setup was conducted in parallel.

After incubation, DNA was extracted from all replicate SIP-1 and SIP-2 BPS+ systems following the SDSbased method described by Zhou et al. ${ }^{28}$ with proportional adaptions in the solution volumes to accommodate $0.25 \mathrm{~g}$ material. No DNA was extracted from BPS- material since linuron was not mineralized. The DNA was dissolved in $10 \mathrm{mM}$ Tris- $\mathrm{HCl}$ buffer $(\mathrm{pH} 8)$. In case of SIP-1, DNA extracts of 5 replicates were pooled for each tested condition and the pooled DNA and residual non-pooled DNA extract were analyzed separately. Similarly, SIP-2 DNA extracts were pooled and the pooled DNA analyzed.

117 In both SIP-1 and SIP-2, isopycnic ultracentrifugation on a linear CsCl gradient and collection of fractions 118 after centrifugation were performed as described ${ }^{29}$. The buoyant density of the fractions was 119 determined through measurement of the refractive index using a AR200 Digital Refractometer (Reichert, 120 Depew, NY ${ }^{30}$. The DNA in the fractions was precipitated using a PEG6000 solution (30\%), washed with 121 ethanol (70\%), eluted in $10 \mathrm{mM}$ Tris- $\mathrm{HCl}$ buffer $(\mathrm{pH} 8)$ and stored at $-20^{\circ} \mathrm{C}$.

122 Culture-dependent enrichment of linuron degraders. Two hundred mg of BPS material was incubated in $123100 \mathrm{~mL}$ Erlenmeyer flasks containing $10 \mathrm{~mL}$ of $\mathrm{MMO}$ medium ${ }^{8}$ (containing ammonium to avoid $\mathrm{N}$ -

124 limitation) amended with $20 \mathrm{mg} \mathrm{L}^{-1}$ linuron as the sole carbon source. Linuron concentrations were 125 determined over time as explained ${ }^{31}$. When the linuron concentration was below detection $\left(3 \mu \mathrm{g} \mathrm{L}^{-1}\right), 1$ $126 \mathrm{~mL}$ of the culture was transferred to fresh linuron $\left(20 \mathrm{mg} \mathrm{L}^{-1}\right)$ containing MMO medium. Transfer of the 127 culture was conducted twice. The second transfer was conducted in triplicate to obtain sufficient 128 biomass for DNA extraction. Upon linuron depletion, the three replicate cultures were pooled and DNA was extracted using a CTAB (cetyl trimethylammonium bromide) based DNA extraction method ${ }^{32}$ 
131 The sequences of the primers used for PCR and the PCR conditions are reported in supplementary table

132 S1. PCR reactions were performed in a Biometra thermocycler (Analytik Jena, Germany) or Eppendorf

133 Mastercycler (Eppendorf, Germany) apparatus. PCR products were visualized after agarose gel

134 electrophoresis (1.5\%) in Tris-acetate/EDTA buffer (90 V for $1 \mathrm{~h}$ ) using GelRed. 16S rRNA gene fragments

135 for DGGE were amplified by PCR using bacterial primer sets $63 \mathrm{~F}$ and $518 \mathrm{R}^{33}$ or $8 \mathrm{~F}$ and $533 \mathrm{R}^{34}$. Forward

136 primers contained a GC clamp sequence (5'-CGCCCGCCG CGCGCGGCGGGCGGGGCGGGGGCACGGGGGG-

$\left.1373^{\prime}\right)$ at the $5^{\prime}$ end. In case of insufficient amplification, a nested PCR approach was implemented using the

138 bacterial $16 \mathrm{~S}$ rRNA gene primers GM3F and $908 \mathrm{R}$ in the first $\mathrm{PCR}^{34}$. DGGE was performed in a C.B.S

139 scientific (Del Mar, CA) DGGE system using 8\% acrylamide gels with a linear denaturing gradient ranging

140 from $35 \%$ to $65 \%$ of urea and formamide and was operated at $120 \mathrm{~V}$ for $16 \mathrm{~h}$ as described 35 .

141 16S rRNA gene amplicon sequencing and data analysis. For $16 \mathrm{~S}$ rRNA gene amplicon sequencing a

142 nested PCR was performed. The first PCR targeted the V1-V5 region of the bacterial 16S rRNA gene using

143 primers $\mathrm{GM} 3 \mathrm{~F}$ and $908 \mathrm{R}^{34}$. PCR conditions are reported in supplementary table S1. The obtained V1-V5

144 amplicons were purified using the QIAquick PCR Purification Kit (Qiagen, Germany) and used as

145 template for the second PCR. The second PCR targeted the V4 region using primers A519F and $802 \mathrm{R}^{34}$

146 amended with overhang adapter sequences. The amplicons were obtained and purified according to the

147 Illumina "16S Metagenomic Sequencing Library Preparation" protocol (Illumina, San Diego, CA).Library

148 preparation, sequencing on the Illumina MiSeq platform and sequencing analysis were performed as

149 described ${ }^{36}$. Quality control and sequencing analysis resulted in 83.531 reads per sample after

150 subsampling according to the sample with the lowest number of valid reads. Phylogeny was assigned

151 using Silva Database V.128 37,38 and sequences grouped in Operational Taxonomic Units (OTUs) at an

152 identity threshold of $97 \%$. Rarefaction analysis and Good's coverage determination were done as

153 described ${ }^{36}$. Sequence analysis was performed on Biolinux $8^{39}$. 
Cloning and Sanger sequencing of 16S rRNA gene amplicons. 16S rRNA gene amplicons, obtained using primer set $27 \mathrm{~F}$ and $1492 \mathrm{R}$ or $8 \mathrm{~F}$ and 533R using the PCR conditions described in supplementary table S1, were cloned into E. coli (Mix \& go Competent Cells - Strain Zymo 5 $\alpha$, Zymo Research, Irvine, CA) using the TOPO TA cloning kit (Invitrogen, Carlsbad, CA). Cloned 16S rRNA gene fragments were sequenced using the $27 \mathrm{~F}$ and $1492 \mathrm{R}$ or $8 \mathrm{~F}$ and $533 \mathrm{R}$ primers on a Sanger platform (GATC Biotech AG, Germany), retrieving around 1300 bp or 520 bp long 16S rRNA gene sequences, respectively. Sequence similarity was determined using NCBI Blast ${ }^{40}$. Maximum likelihood phylograms of relevant $16 \mathrm{~S}$ rRNA gene sequences were obtained after alignment using Muscle v3.8.31 ${ }^{41}$ and implementing an $1000 x$ bootstrap analysis using RAxML v.8.2 $2^{42}$.

\section{RESULTS}

\section{Linuron mineralization activity in BPS material and selection of time points for DNA-SIP analysis.}

DNA-SIP experiments were initiated at day 180 (SIP-1) and day 440 (SIP-2) from BPS ${ }^{+}$and BPS-

microcosm materials. Mineralization was monitored based on $\mathrm{CO}_{2}$ production from ${ }^{14} \mathrm{C}$-labeled linuron.

168 Linuron was clearly mineralized, but only in the BPS ${ }^{+}$microcosms, with a $35 \%$ to $50 \%$ conversion to $\mathrm{CO}_{2}$, with the residual carbon likely assimilated into biomass (Figure S1). The assumption that mineralization was accompanied by growth was supported by the mineralization kinetics, which fitted the Gompertz

171 kinetic model ${ }^{43}$. Kinetics of linuron mineralization differed between SIP-1 and SIP-2. The lag phase was 172 shorter in SIP-2 as compared to SIP-1, likely because the material of the BPS $^{+}$microcosms contained a

173 higher number of linuron-degraders due to the longer feed with linuron ${ }^{16,19,25,44}$. Furthermore, more $\mathrm{CO}_{2}$

174 was produced in SIP-1 compared to SIP-2. Differences in $\mathrm{CO}_{2}$ from linuron mineralization were reported 175 previously ${ }^{44}$. In order to avoid cross-labeling of peripheral populations, it was decided to take samples 176 for DNA-SIP in the late exponential phase, when most linuron was likely mineralized, maximum growth 177 was attained and no decay of the linuron mineralizers was expected yet. 
DNA-SIP: microbial community analysis. For both SIP-1 and SIP-2, heavy ${ }^{13}$ C-labeled DNA fractions that

179 showed distinct DGGE bands compared to other DNA fractions of the ${ }^{13} \mathrm{C}$-linuron amended incubations, as well as to the non-labeled DNA fractions of corresponding density, were identified (Figure S2). In SIPclosely located unique bands (Figure S2 panel B). DGGE analysis that compared relevant SIP-1 and SIP-2 fractions using the same primer set for $16 \mathrm{~S}$ rRNA gene amplification, revealed that the lower unique band in the ${ }^{13} \mathrm{C}$-DNA fraction of SIP-1 consisted of two closely migrating bands that migrated similarly to the two unique bands found in the ${ }^{13} \mathrm{C}$-DNA fractions of SIP-2. The upper unique band in the ${ }^{13} \mathrm{C}-\mathrm{DNA}$ fraction of SIP-1 consisted of two closely migrating bands but with no counterpart in the SIP-2 ${ }^{13}$ C-DNA fractions (Fig S2 panel C). Based on the DGGE results, relevant fractions (see Figure S2 panel B) obtained from the ${ }^{13} \mathrm{C}$-linuron amended samples and corresponding samples from the unlabeled linuron amended samples, were selected for $16 \mathrm{~S}$ rRNA gene amplicon sequencing. In case of SIP-2, the respective fractions were pooled prior to sequencing. 16S rRNA gene amplicons obtained from non-fractionated DNA of SIP-1 was likewise sequenced.

192 Rarefaction curves of the sequence reads showed full asymptotes or at least $98 \%$ coverage, indicating 193 robust taxonomic sampling (Figure S3, Table S2). A clearly increased relative abundance of an OTU 194 assigned to the genus Ramlibacter was observed in the heavy fractions of the SIP-1 ${ }^{13}$ C-linuron amended 195 samples (37\%-39\% relative abundance), compared to its proportion in the light density DNA fractions of 196 the ${ }^{13} \mathrm{C}$ - labeled linuron amended samples $(0.08 \%$ - $0.09 \%)$ and in the non-fractionated DNA from ${ }^{13} \mathrm{C}$ -

197 linuron amended samples (0.8\% - 0.95\%). The relative abundance of Ramlibacter-associated sequences 198 was also significantly lower in both heavy $(0.62 \%-1.3 \%)$ and light $(0.17 \%-0.5 \%)$ DNA fractions of the

$199{ }^{12} \mathrm{C}-$-linuron amended samples and in DNA of the non-labeled linuron amended samples prior to centrifugation (0.57\% - 0.95\%) (Figure 1 panel A). Highly similar results were found for the non-pooled 201 replicate DNA extracts (Figure S4), suggesting Ramlibacter as the organism assimilating the carbon from 
202 linuron in the BPS. However, Ramlibacter is closely related to Variovorax and we found that the $16 \mathrm{~S}$

203 rRNA gene of Variovorax type strains can exhibit up to $99.27 \%$ sequence similarity in the V4 region with

204 Ramlibacter species, implying that Variovorax sequences could have been mistakenly assigned to the

205 Ramlibacter OTU. Manual inspection of the individual sequences assigned to the Ramlibacter OTU,

206 revealed that a sequence $100 \%$ identical to the V4 region of various Variovorax strains and in particular

207 of a clade of strains that includes most of the linuron degrading Variovorax sp. strains (such as strains

208 WDL1, PBS-H4 and PBL-H6), contributed significantly (i.e., $10.11 \pm 1.59 \%$ ) to the Ramlibacter OTU. Both

209 Ramlibacter and Variovorax sequences showed a high impact of the ${ }^{13} \mathrm{C}$-labeling on relative abundances,

210 i.e., the Ramlibacter sequences showed a 70-fold and 59-fold increase in the heavy ${ }^{13}$ C-DNA fractions

211 compared to the heavy non-labeled DNA fractions and the samples prior to centrifugation, respectively,

212 while the Variovorax associated sequences displayed an 11-fold increase and 34 fold increase,

213 respectively. We conclude that next to Ramlibacter, also Variovorax and especially strains belonging to

214 its "linuron degrading" clade assimilated the carbon from linuron in SIP-1.

215 The OTU related to Ramlibacter was also the only enriched OTU in the ${ }^{13} \mathrm{C}$-linuron amended fractions in

216 SIP-2. The OTU showed a 18 - and 17 -fold higher abundance in the heavy ${ }^{13} \mathrm{C}$-DNA fractions (4.7\%)

217 compared to its abundance in the total community DNA prior to centrifugation $(0.26 \%)$ and to the

218 corresponding fractions of the non-labeled linuron amended systems (0.27\%), respectively (Figure 1

219 panel B). Variovorax associated sequences were not recovered in the heavy DNA fractions of the ${ }^{13} \mathrm{C}-$

220 labeled sample.

221 The observation that Variovorax sequences were erroneously assigned to the Ramlibacter OTU and the

222 knowledge that Variovorax is a well-known linuron degrader while Ramlibacter is not, prompted us to

223 obtain more sequence evidence for the involvement of Ramlibacter in linuron assimilation in the BPS

224 environment. To this end, almost full 16S rRNA gene sequences were obtained from the ${ }^{13} \mathrm{C}$-DNA

225 fractions of SIP-1 by random cloning and sequencing of 16S rRNA gene amplicons recovered using 
primers $27 \mathrm{~F}$ and $1492 \mathrm{R}$. Three cloned $16 \mathrm{~S}$ rRNA gene fragments showed dual banding patterns on DGGE

227 that corresponded to the unique two lower DGGE bands found in the ${ }^{13}$ C-DNA fractions of SIP-1 and SIP-

2282 (represented by clone 3.1, Figure 2) and their sequences phylogenetically most related to the

Ramlibacter genus showing $98.4 \%-98.7 \%$ identity to Ramlibacter type species 16 S rRNA sequences and

$95.8 \%-96.1 \%$ to Variovorax sequences (Figure 3). However, none of the clones corresponded to the

two other (higher) unique bands observed in ${ }^{13} \mathrm{C}$-DNA fractions of SIP-1. Therefore, these bands were cut

from the gel and cloned. Two clones (DGGE 12 and DGGE 18) displayed the dual band migration at the expected location in the DGGE gel (Figure S5). As found for clone 3.1, the 520 bp sequences of the DGGE-clones 12 and 18, which do not include the V4 region, related most to Ramlibacter (Figure S6). Interestingly, while the almost full length 16S rRNA clones identified as Ramlibacter showed 99.8\% $100 \%$ identity to one another in that region, they showed only $97.3 \%-98.3 \%$ identity to the DGGE

237 clones. The clones obtained from the DGGE bands show a seemingly identical DGGE migration pattern 238 as the linuron degrading isolate Variovorax sp. WDL1, whose V4 region of the 16S rRNA sequence is 239 identical to the sequence of the SIP-1 Variovorax subpopulation. However, comparison of the sequences 240 through BLAST alignment supported the assignment of those clones to the Ramlibacter genus (97.2$24197.8 \%$ identity) rather than the Variovorax genus $(94.8 \%-94.9 \%$ identity to type species, $95.4 \%-96 \%$

242 identity to linuron degrading strains), which was further supported by phylogram calculation (Figure S6).

243 Cloning of the SIP-1 DNA-fractions produced no clones that related to Variovorax, while cloning of the 244 SIP-2 DNA-fractions did not produce any clones derived from Ramlibacter or Variovorax, likely due to 245 the its relatively low abundance compared to other OTUs.

246 DNA-SIP: functional gene analysis. The DNA-SIP fractions were tested by PCR for the presence of 247 marker genes related to linuron catabolism, i.e., hylA, libA and $d c a Q$ as well as to horizontal gene 248 transfer (HGT) and MGEs, i.e., the IncP1-plasmid marker gene trfA and the insertion sequence IS1071 249 that were previously associated with linuron catabolic genes ${ }^{6,14,15}$. In SIP-1, the three catabolic markers 
250

251

252

253

254

255

256

257

258

259

260

261

262

263

264

265

266

267

268

269

270

271

272

273

and the two MGE markers, were enriched in the heavy fractions of the ${ }^{13} \mathrm{C}$-linuron amended samples while little or no amplification occurred in the low density fractions of the ${ }^{13} \mathrm{C}$-linuron amended samples and in the corresponding fractions of the non-labeled linuron amended systems. Instead, amplification was observed in the lower density DNA fractions of the non-labeled linuron amended systems (Figure 4 panel A). The SIP-2 fractions exhibited similar results with few exceptions. libA was not amplified in any of the DNA fractions (Figure 4 panel B). Moreover, the shift of IS1071 towards the heavy fractions of the ${ }^{13} \mathrm{C}$-linuron amended sample, was less pronounced than in SIP-1 and trfA showed an even distribution across all fractions derived from both the ${ }^{13} \mathrm{C}$-linuron and non-labeled linuron amended sample.

Cultivation-dependent isolation: enrichment of linuron degraders from BPS material. A soil-free EC that rapidly degraded linuron was obtained from the original BPS sample material (Figure S7).

Rarefaction analysis of the $16 \mathrm{~S}$ rRNA gene amplicon reads suggested robust sampling with high coverage (Figure S3, Table S2). The EC was dominated by 3 major OTUs identified as Pseudomonas (31\%), Variovorax (19\%) and an unclassified genus associated with the Comamonadaceae family (17\%) (Figure

5). The Variovorax OTU related to the clade of linuron degrading Variovorax isolates and the unclassified Comamonadaceae to Acidovorax. Other notable OTUs were associated with Hyphomicrobium (7\%), Comamonas (4\%), and a second unclassified Comamonadaceae OTU (4\%). The latter OTU was comprised of 50\% Rhodoferax and 50\% Variovorax sequences of which the Variovorax sequences most related to Variovorax boronicumulans, suggesting the presence of at least two distinct Variovorax populations in the EC. No Ramlibacter associated sequences were recovered (Figure 5). To acquire further information on the phylogeny of the EC organisms, almost full 16S rRNA genes were cloned, sequenced and phylogenetically analyzed as well as analyzed by DGGE. The sequencing of the $16 \mathrm{~S}$ rRNA gene clones agreed with the amplicon sequencing results. Two clones not only shared $98.85 \%$ sequence similarity in the near full-length $16 \mathrm{~S}$ rRNA sequence with one another, but also identically matched the V4 region of the Variovorax sequences recovered through amplicon sequencing. Phylogenetically the 
clones related most to the reported Variovorax clade containing the linuron degraders (Figure 3). A third

275 clone showed $99.6 \%$ similarity to the Comamonas OTU and corresponded to the 16S rRNA gene sequence of a Comamonas strain previously isolated from linuron degrading consortia ${ }^{8,10}$ (Figure 3), while the two remaining clones most related to Acidovorax, matching the Acidovorax OTU consensus 278 sequence (99.6\% and 100\%). Clear differences were evident between the EC community DGGE profile 279 and the profiles obtained from the SIP-1 and SIP-2 ${ }^{13} \mathrm{C}$-fractions, most notably the absence of the Ramlibacter associated band represented by SIP-1 clone 3.1, in the EC community. Note that the band derived from EC clone 1.10 migrated to the same height as the (upper) unique DGGE band identified in the SIP-1 ${ }^{13}$ C-DNA fraction (identified as Ramlibacter), migrated to the same height as the band derived from EC clone 1.10, despite having different sequences in the region used for DGGE analysis. The EC exhibited PCR amplification of all tested catabolic and MGE marker genes (data not shown).

\section{DISCUSSION}

\section{Relevance of the selected sampling time points for identification of in situ linuron degraders through}

DNA-SIP. In the present study, we identified the organisms responsible for linuron in situ mineralization in a BPS environment through application of DNA-SIP. The time point of DNA extraction after the addition of ${ }^{13} \mathrm{C}$-labeled linuron was chosen in the late logarithmic growth phase of the mineralizing

291 bacteria, as indirectly determined through monitoring ${ }^{14} \mathrm{CO}_{2}$ production from ${ }^{14} \mathrm{C}$-labeled linuron. The

292 cumulative mineralization curves showed a logarithmic profile and fit the Gompertz kinetic model,

293 indicating that the compound was mineralized along with growth and that no growth/assimilation on/of 294 decaying cells occurred. Indeed, in case of the latter, deviations in the mineralization profile, such as a 295 dual mineralization phase, would be expected. Moreover, the observation that only a limited number of 296 genera was enriched in the ${ }^{13} \mathrm{C}$-DNA fractions, including one known linuron degrading genus along with 297 known linuron catabolic genes, suggests that true linuron assimilators were targeted without cross- 
labeling of peripheral populations. Therefore, we conclude that the selected time points for SIP analysis were relevant to identify microbiota directly involved in in situ linuron assimilation in the examined BPS.

\section{DNA-SIP identifies Variovorax and Ramlibacter as contributors to in situ linuron degradation in BPS.}

The SIP approach suggested that members of the Comamonadaceae family, more specifically of the genera Ramlibacter and, to a lesser degree, Variovorax are implicated in the in situ assimilation of ${ }^{13} \mathrm{C}$ derived from linuron. Variovorax strains have often been isolated as linuron degraders and several studies have indicated their involvement in in situ biodegradation in agricultural soil and in the BPS environment ${ }^{14,16-19}$. However, this study for the first time unequivocally links the genus Variovorax, and in particular the Variovorax clade harboring most linuron degrading Variovorax isolates, to in situ linuron degradation, emphasizing the ecological relevance of this clade for linuron biodegradation. Other linuron degrading isolates belong to genera like Hydrogenophaga and Diaphorobacter, in the Comamonadaceae family, Mycobacterium and Arthrobacter (Actinobacteria) and Achromobacter (Alcaligenaceae) ${ }^{10,45-47}$ but none of those could be linked with in situ linuron assimilation in the studied BPS environment. Instead, in addition to Variovorax, the genus Ramlibacter was found as being involved in the in situ degradation of linuron. Moreover, the organism even dominated the linuron assimilating population and likely involved at least two different genotypes as indicated by the DGGE analysis. In contrast to Variovorax, no Ramlibacter member has yet been isolated as a linuron degrader, but the genus was recently reported to be enriched in another linuron-fed BPS environment along with other genera like Variovorax, Hydrogenohaga (Comamonadaceae) and Hyphomicrobium (Alphaproteobacteria $)^{14}$. Interestingly, Ramlibacter has been associated with the biodegradation of organic contaminants including natural occurring aromatic compounds, i.e., bipheny ${ }^{48}, m$-xylene ${ }^{49}$ and phenol ${ }^{50}$ as well as xenobiotics, i.e., the herbicide 2,4 -dichlorophenoxyacetic acid $(2,4-D)^{51}$ and the plasticizer di-(2 ethylhexyl) phthalate (DEHP) ${ }^{52}$ but these only involve culture-independent studies that make use of either DNA-SIP or metagenomics. The Ramlibacter genus currently includes only few 
322 isolated species obtained from various environments like soil and a cooling water system ${ }^{53-59}$. The SIP-2

323 experiment suggested Ramlibacter as the only organism involved in linuron assimilation, while

324 Variovorax was not detected. This, however, does not necessarily imply its complete absence, but

325 instead might be due to a reduced abundance below detection within the background community, 326 despite robust sampling. This is supported by the observation that Ramlibacter was also significantly

327 lower in relative abundance in SIP-2 compared to its abundance in SIP-1. A plausible explanation is that 328 less linuron was degraded and hence assimilated, also causing the observed decreased $\mathrm{CO}_{2}$ production 329 compared to SIP-1. However, $\mathrm{CO}_{2}$ production and carbon assimilation can vary depending on a plethora 330 of factors ${ }^{60}$. Alternatively, the decreased relative abundance might involve changes in background community composition and more specifically the fact that some OTUs increased considerably in absolute numbers, changing the relative contribution of other OTUs. A change in background microbial community composition was indeed observed between SIP-1 and SIP-2. The reasons for this change is unknown, but the BPS environment provides a variety of carbon substrates which likely vary in biodegradability and as such could sustain successional colonization by different communities and

336 involve complex interactions of both degraders and non-degraders. Known linuron catabolic genes drive linuron biodegradation in BPS and appear linked to presence of MGEs. A set of genes, representing essential steps in the canonical pathway for linuron metabolism ${ }^{8}$ were enriched in the ${ }^{13} \mathrm{C}$-DNA fractions, consistent with the observed assimilation of linuron carbon into cellular material, suggesting that this well-known pathway is being followed in situ. hylA and libA encode

341 two iso-functional linuron hydrolases that belong to two different hydrolase families (amidohydrolase 342 and amidase signature family, respectively), showing the involvement of redundant linuron hydrolysis 343 functionalities in the BPS. The catabolic genes show distinct dynamics as indicated by the differences 344 between SIP-1 and SIP-2. Notably, the lack of detectable libA in SIP-2 was striking, indicating that its 345 hosts were less competitive in the system at day 440. Previously, we have shown dynamics of both hylA 
and libA as well as of $d c a Q$ by means of qPCR in linuron impacted BPS material and agricultural soil ${ }^{19}$.

347 The examined catabolic genes were previously identified in Variovorax but also in other $\beta$ proteobacteria especially in the Comamonadaceae family, which includes Ramlibacter, therefore their association with Ramlibacter is plausible. Other catabolic genes linked to linuron biodegradation were not tested and hence we cannot exclude their involvement in linuron degradation in the BPS. These genes include puhA and puhB that encode for broad substrate range phenylurea hydrolases belonging to the amidohydrolase family, but those were identified in phenylurea degrading Actinobacteria and were never linked with linuron metabolism ${ }^{45,46}$. Recently, phh (amidohydrolase related to PuhA and PuhB) and tccA2 (amidase family) were identified as encoding for two new broad substrate phenylurea hydrolases in another member of the Comamonadaceae family, Diaphorobacter sp. strain LR2014-1, belonging to a linuron mineralizing consortium ${ }^{47}$. Apart from known linuron catabolic genes, MGE marker genes were

357 also enriched in the ${ }^{13} \mathrm{C}$-DNA fraction indicating that these genes were present in the linuron assimilating organisms that carry the detected linuron biodegradation genes and that they are prone to HGT. Although we do not have evidence that the catabolic genes are linked physically with the MGE, this is likely the case. Genome sequences of linuron degrading organisms, including Variovorax, show the presence of IS1071 in conjunction with most, if not all of the catabolic genes (like hylA, libA, dcaQ) $)^{15,61}$. The presence of IS1071 and its conjunction with linuron degradation genes in the BPS environment was shown before ${ }^{5,6}$ and likely IS1071 contributes significantly to the genetic adaptation to degrade pesticides in the BPS environment ${ }^{6}$. Similarly, linuron catabolic genes like $h y / A$ and $d c a Q$ have been linked to IncP-1 plasmids in isolates from agricultural soils, as well as to plasmids exogenously derived from a BPS environment ${ }^{14,20}$. On those plasmids, the linuron catabolic genes are commonly embedded in 367 an IS1071 associated composite transposon which might explain the co-enrichment in the ${ }^{13} \mathrm{C}$-fraction of both trfA and IS1071 in SIP-1. Apart from IncP-1 plasmids, IS1071 composite transposons carrying linuron catabolic genes can be transferred to other replicons $s^{6,15}$. This might explain why the shift of $\operatorname{trfA}$ 
towards the heavy ${ }^{13} \mathrm{C}$-labeled DNA fractions was not observed in SIP-2. Instead, the presence of IncP-1

371 plasmids in all SIP-2 fractions might be linked to the promiscuity and high transferability of IncP-1

372 plasmids ${ }^{62}$.

373 Assigning linuron biodegradation activity to DNA-SIP-identified populations. Despite the enrichment of

374 Ramlibacter and Variovorax and the identification of genes known to be involved in linuron assimilation,

375 the functions cannot be unequivocally assigned to either organism, especially since linuron is

376 metabolized by both single strains and consortia. In consortia, linuron is hydrolyzed to 3,4-DCA and N,O-

377 dimethylhydroxylamine $(\mathrm{N}, \mathrm{O}-\mathrm{DMHA})$ by a first organism, often Variovorax, and 3,4-DCA is further

378 mineralized by other organisms while $N, O-D M H A$ is utilized by methylotrophic bacteria like

Hyphomicrobium $^{8}$. The fact that multiple microbiota were labeled through DNA-SIP makes the

degradation by consortia plausible. In our study, linuron was ${ }^{13} \mathrm{C}$-labeled in the ring structure, and hence microbiota that assimilated the aromatic ring carbon are expected to be labeled and not necessarily those that hydrolyze linuron. However, the observation that typical linuron hydrolysis genes like hylA and libA were enriched in the ${ }^{13} \mathrm{C}$-DNA suggests that either (i) degradation of the compound in parallel by several individual strains or (ii) that linuron hydrolyzers that perform complete linuron mineralization, leak a part of the produced DCA to other bacteria. Recently, a more complex, not yet fully elucidated, carbon flow network in linuron degrading consortia was suggested, where Variovorax performs the unproductive hydrolysis step, and despite lacking the $d c a$ cluster, receives a substantial portion of carbon. The mechanism is currently unknown, but could involve transfer of linuron derived carbon from organisms that degrade the aromatic structure, back to the linuron hydrolyzer ${ }^{15}$. The observation that the catabolic genes are likely linked to MGEs, further complicates the situation since the genes could be

391 (temporally) exchanged between different members of a consortium and as such change the catabolic 392 properties continuously. Interestingly, the disappearance of libA in SIP-2 compared to SIP-1 was 
disappearance of one of the Ramlibacter associated bands in the DGGE profiles. This might suggest that

395 at least one of them carried libA and that the remaining Ramlibacter carried both $h y / A$ and dcaQ, likely enabling it to perform the complete pathway on its own, at least at day 180 .

Community composition of the linuron degrading enrichment culture suggests robustness of

linuron degrading EC from the BPS, showed near to no similarity to results obtained through the DNA-

SIP approach and instead identified genera previously isolated as members of linuron degrading and functional similarity of this consortium, which represents the first linuron degrading consortium enriched from a BPS environment, to previously reported linuron degrading consortia from arable soil, is striking and suggests strong robustness in enriching such consortia independent of the target environment, at least under the implemented conditions. We purposefully utilized minimal media and culture conditions that were similar to previous studies, but we cannot exclude the possibility of

407 enriching differently composed consortia when alternate culture approaches are used. Recently, a 408 substantially different consortium including Diaphorobacter and Achromobacter was described ${ }^{47}$. 409 However, no consortium which includes Ramlibacter as a prominent linuron assimilator has been 410 described to date.

411 In the here described EC, all examined catabolic and functional genes were found to be present, 412 including libA. Interestingly, the sequence of the dominant Variovorax type matches the sequence of the 413 Variovorax subpopulation identified in SIP-1, suggesting that in the cultivation process, Variovorax has 414 completely replaced Ramlibacter in its function. The mechanisms that define the non-competitive 415 nature of Ramlibacter in the EC and its competitive nature in the BPS are unknown. The BPS 416 environment, containing solid surfaces and various other nutrient sources, differs significantly from the 417 suspended culture system in defined media. Moreover, the complex BPS environment might impact 
418 linuron and nutrient bioavailability. While the medium used in the EC differs in nitrogen availability, it is 419 unlikely to be the ultimate cause of the difference, since the BPS material itself contains other nitrogen 420 sources. Additional consideration can be given to the fact that the EC was initiated directly from the BPS 421 material prior to linuron treatment in microcosms, while the SIP incubations were initiated using BPS

422 material enriched with linuron. However, it is again unlikely that this can cause the observed 423 differences, as several other enrichments that were since initiated from linuron treated BPS, resulted in 424 highly similar communities (data not shown). The implication of several transfers in the EC might 425 contribute to the observed differences, since these will especially benefit rapidly growing organisms. 426 Interestingly, slow growth and necessity for additional growth factors were reported for several 427 Ramlibacter isolates, suggesting poor fitness under standard culturing conditions $s^{53,54}$.

428 Although the community composition strongly differs, all tested linuron catabolic genes and MGE 429 markers were found to be present in the organisms identified by DNA-SIP and in the EC. This is partly explained by the presence of Variovorax in both the SIP-1 system and in the EC and might be further

431 explained by the apparent mobile character of the catabolic genes. Overall, our study provides evidence 432 of the environmental role of the common linuron degrading isolate Variovorax in in situ linuron 433 biodegradation, but also that culturing approaches might only provide a partial picture of the 434 populations responsible for in situ linuron biodegradation.

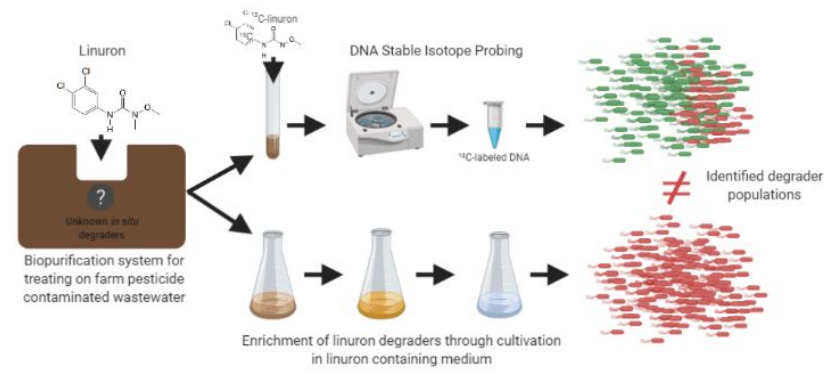




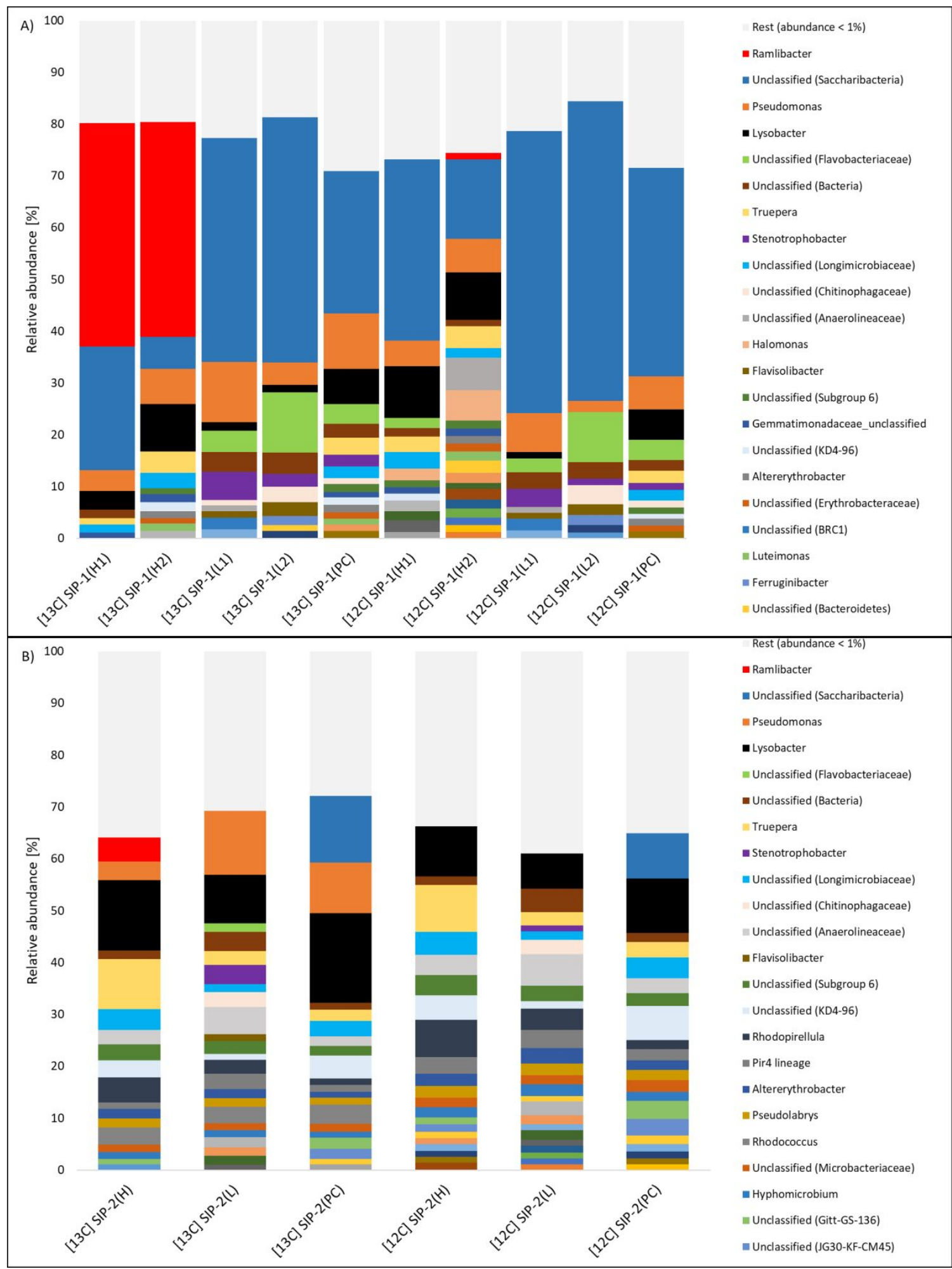

Figure 1. 16S rRNA gene amplicon diversity (genus level) in selected high and low fractions density DNA fractions in the SIP-1 (A) and SIP-2 (B) experiment. OTUs were assigned with a 97\% identity threshold. For SIP-1 two separate heavy $(\mathrm{H})$ and light $(\mathrm{L})$ fractions are depicted for both ${ }^{13} \mathrm{C}$-labeled and non-labeled $\left({ }^{12} \mathrm{C}\right)$ DNA. For SIP-2 three heavy 
$443(\mathrm{H})$ and three light $(\mathrm{L})$ fractions were pooled prior to sequencing. DNA samples of the respective SIP-incubations 444 prior to ultracentrifugation were analyzed as well for both SIP-1 and SIP-2 (indicated as PC).

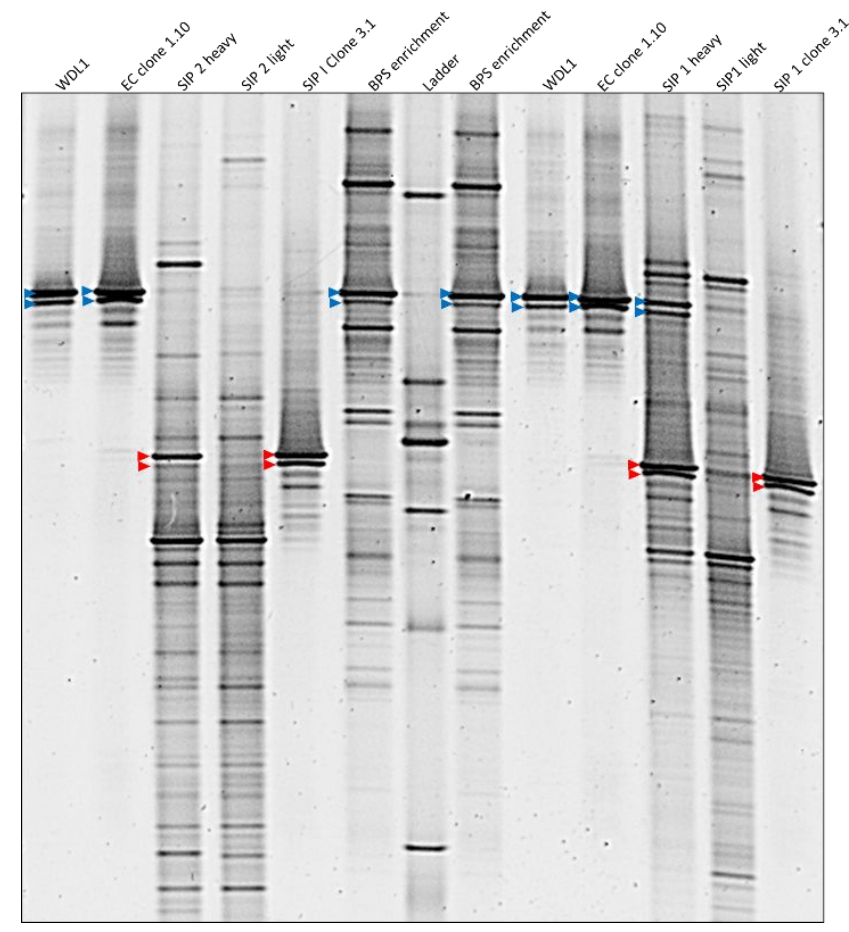

Figure 2. 16S rRNA gene DGGE profiling showing community fingerprints of relevant DNA-SIP density fractions originating from ${ }^{13} \mathrm{C}$-linuron amended $\mathrm{BPS}^{+}$material in SIP-1 and SIP-2, as well as of the linuron degrading enrichment culture $(E C)$. Corresponding amplicons originating from almost full 16SrRNA gene clones obtained from SIP-1 and EC DNA are included along with the corresponding 16 S rRNA gene fragment of the linuron degrading Variovorax sp. WDL1. Primer set 8F and 533R was used for 16S rRNA gene amplification for all samples. Red arrows indicate DGGE bands associated with ${ }^{13} \mathrm{C}$-DNA fraction SIP-1 16S rRNA gene clone 3.1 and the corresponding bands in the ${ }^{13} \mathrm{C}-$ DNA fraction SIP-1 and SIP-2 profiles. Blue arrows indicate bands associated with EC clone 1.10, with Variovorax sp. WDL1 and the corresponding bands in the EC profile. 


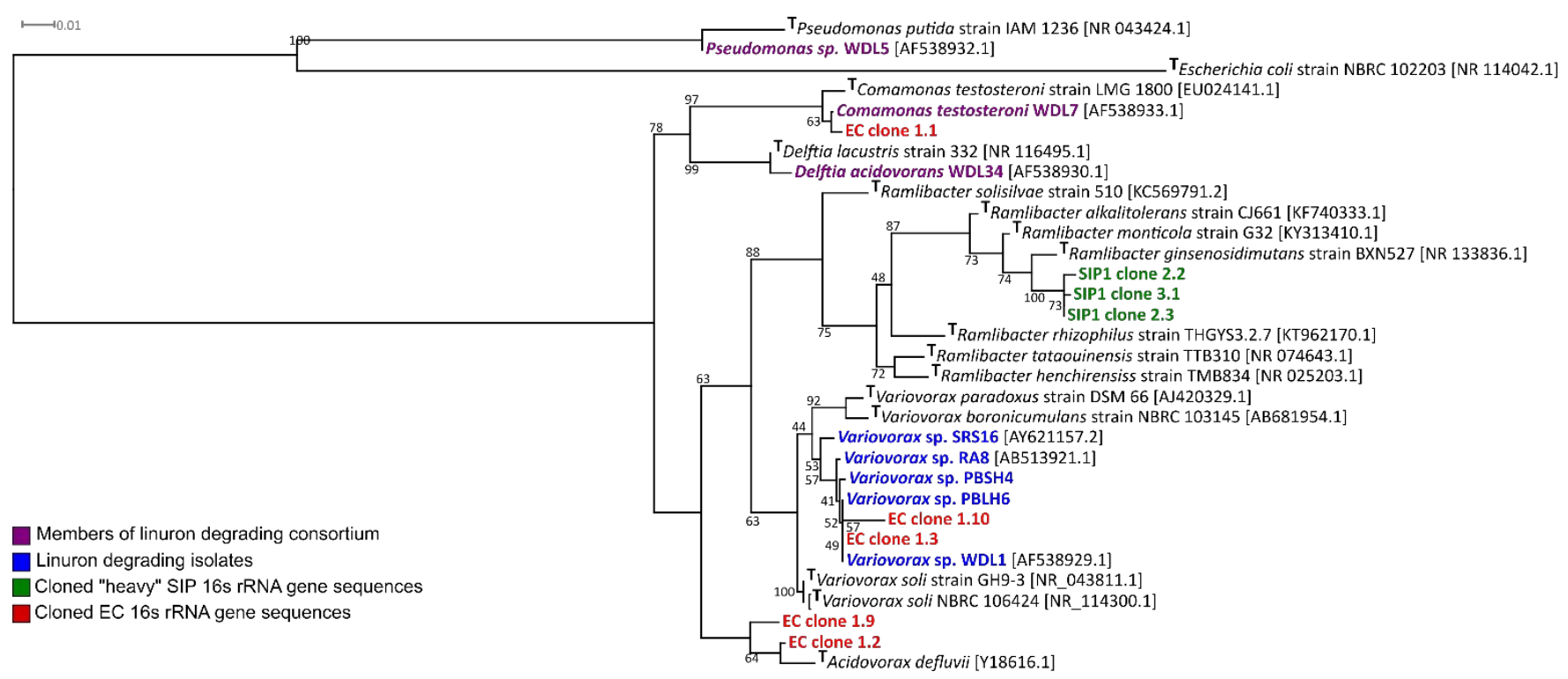

Figure 3. Phylogram showing nearly complete $16 \mathrm{~S}$ rRNA gene sequences recovered by cloning from the ${ }^{13} \mathrm{C}$-DNA 458 fraction of SIP-1 (green) and from the linuron enrichment culture (red), as well as 16S rRNA gene sequences from 459 previously reported linuron degrading strains (blue) and other bacteria implicated in linuron degrading consortia 460 (purple). Bacterial 16S rRNA sequences of type strains related to the afore mentioned bacteria were included to 461 enable correct branch formation. 
A)

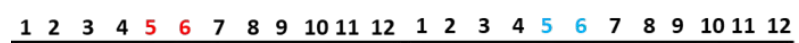

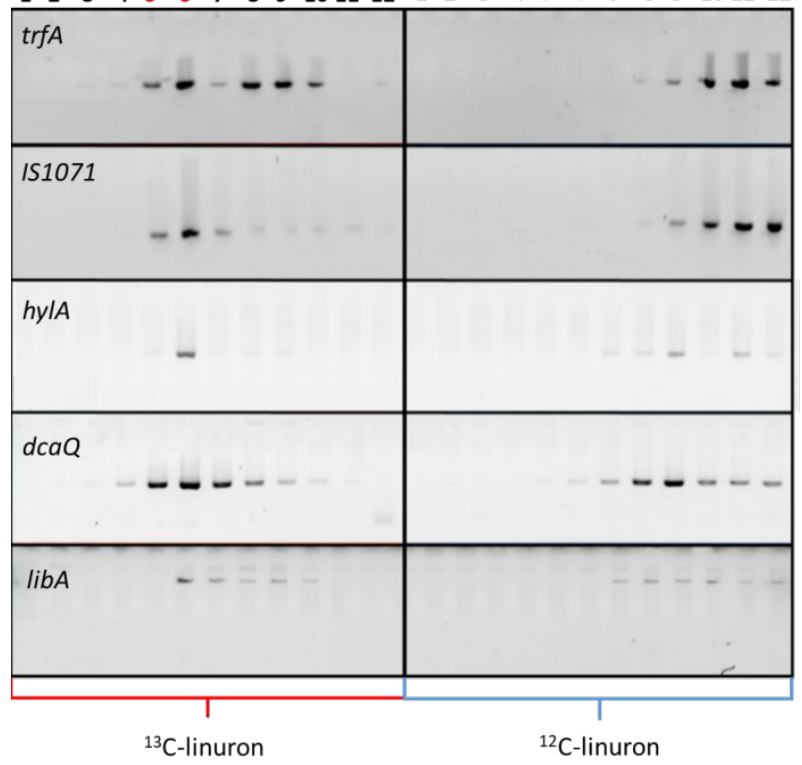

B)

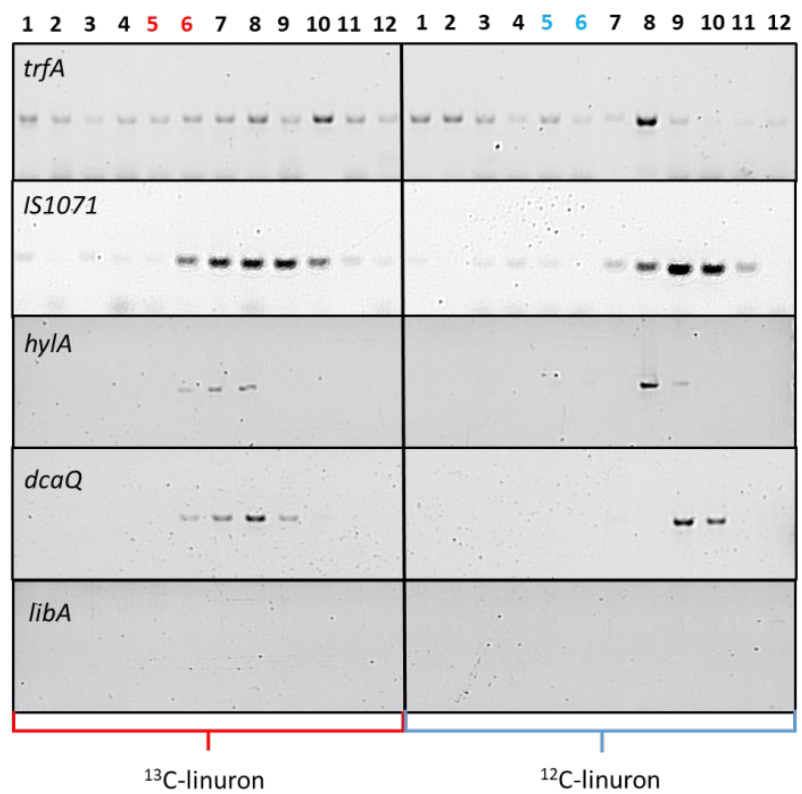

Figure 4. PCR analysis of linuron-catabolic and MGE marker genes in ${ }^{13} \mathrm{C}$ and ${ }^{12} \mathrm{C}$-DNA after fractionation in the SIP-1 (A) and SIP-2 experiment (B). The fraction numbers in the density range expected to contain ${ }^{13} \mathrm{C}$-DNA are indicated in red for DNA derived from $\mathrm{BPS}^{+}$material amended with ${ }^{13} \mathrm{C}$-linuron and in blue for DNA derived from the BPS material amended with non-labeled linuron.

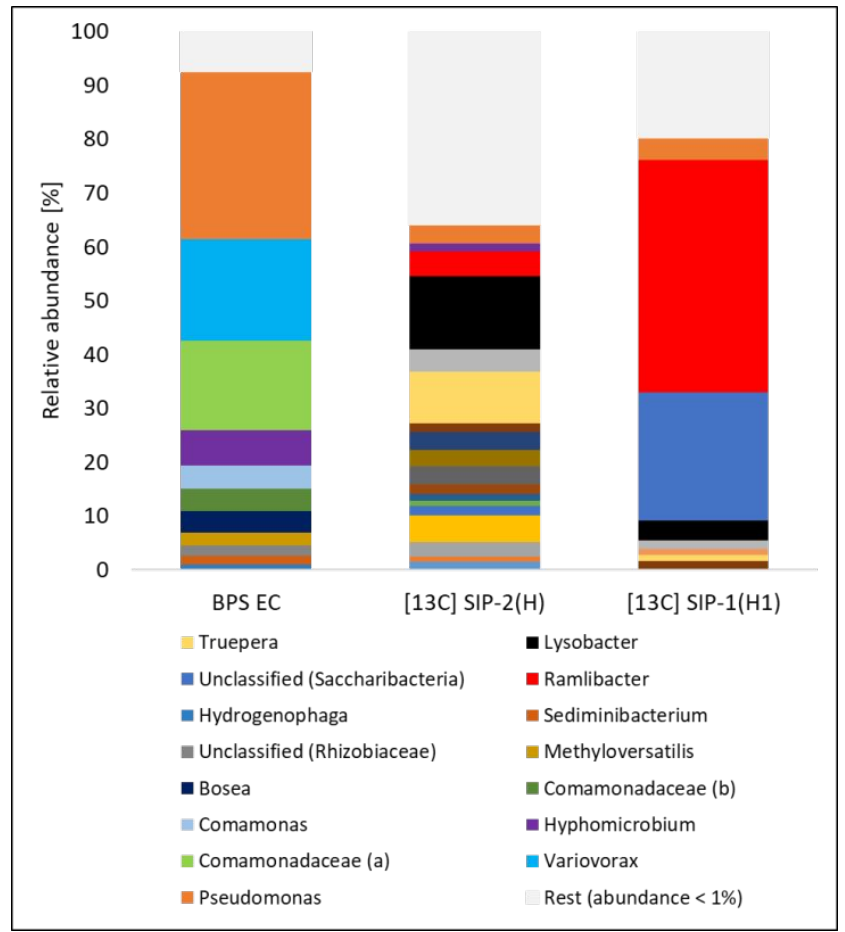

Figure 5. 16S rRNA gene diversity (genus level) in the EC as compared to this of the ${ }^{13} \mathrm{C}-\mathrm{DNA}$ of the SIP-1 and SIP-2 experiment. OTUs were assigned with a $97 \%$ identity threshold. 


\section{ASSOCIATED CONTENT}

\section{Supporting Information}

480 List of pesticides used at Inagro during operational period of the sampled BPS;

481 Method description of in-house synthesis of [phenyl-U-13C] linuron; Information regarding PCR

482 methodology, primer sequences and used PCR programs; ${ }^{14} \mathrm{C}$-linuron mineralization kinetics of SIP-1 and 483 SIP-2 samples including their fit to the Gompertz kinetic model; 16S rRNA gene amplicon DGGE

484 community fingerprints of DNA fractions of SIP-1 and SIP-2 samples; Rarefaction analysis of the SIP-1, 485 SIP-2 and EC samples sequenced on a Illumina MiSeq platform; Good's coverage of the SIP-1, SIP-2 and 486 EC samples sequenced on a Illumina MiSeq platform; OTU graph displaying 16S rRNA gene diversity of 487 the SIP-1 replicate samples; 16S rRNA gene amplicon DGGE fingerprints of DGGE clones 12 and 18 488 derived from DNA retrieved from the upper unique DGGE bands observed in the SIP-1 heavy ${ }^{13}$ C-DNA 489 fractions in comparison to EC clone 1.10 (Variovorax); Phylogram showing V1-3 region sequences of 490 clones 12 and 18 , recovered by cloning from the upper unique DGGE bands identified in the ${ }^{13} \mathrm{C}$-DNA 491 fraction of SIP-1 in comparison to relevant sequences; Degradation activity of the linuron EC over the 492 enrichment period.

493 AUTHOR INFORMATION

494 Corresponding Author

$495 \quad *$ E-mail: dirk.springael@kuleuven.be. Phone: 32163216 04. Fax: 3216321997.

496 ORCID

497 Harry Lerner: 0000-0002-2004-6490

$498 \quad$ Notes

499 The authors declare no competing financial interest. 
501 The Authors thank E. Pauwelyn (Inagro) for providing the BPS material, the technical staff of the Thünen

502 Institut and especially B. Müller for assistance in conducting DNA-SIP. We also thank D. Grauwels and K. 503 Mors for technical assistance. This work was supported by the FWO Project G.0371.06.

(1) Karanasios, E.; Tsiropoulos, N. G.; Karpouzas, D. G. On-farm biopurification systems for the depuration of pesticide wastewaters: Recent biotechnological advances and future perspectives. Biodegradation 2012, 23 (6), 787-802. https://doi.org/10.1007/s10532-012-9571-8.

Torstensson, L.; Castillo, M. Use of biobeds in Sweden to minimize environmental spillages from agricultural spraying equipment. Pestic. Outlook (United Kingdom) 1997.

Castillo, M. D. P.; Torstensson, L.; Stenström, J. Biobeds for environmental protection from pesticide use a review. J. Agric. Food Chem. 2008, 56 (15), 6206-6219.

512 (4) De Wilde, T.; Spanoghe, P.; Debaer, C.; Ryckeboer, J.; Springael, D.; Jaeken, P. Overview of on-farm bioremediation systems to reduce the occurrence of point source contamination. Pest Manag. Sci. 2007, $63(2), 111-128$. 
review. Crit. Rev. Environ. Sci. Technol. 2015, 45 (18), 1947-1998.

https://doi.org/10.1080/10643389.2014.1001141.

525

526

527

528

529

530

531

532

533

534

535

536

537

538

539

540

541

542

543

544

545

546

(8)

Dejonghe, W.; Berteloot, E.; Goris, J.; Boon, N.; Crul, K.; Maertens, S.; Höfte, M.; De Vos, P.; Verstraete, W.;

Top, E. M. Synergistic degradation of linuron by a bacterial consortium and isolation of a single linurondegrading Variovorax strain. Appl. Environ. Microbiol. 2003, 69 (3), 1532-1541.

https://doi.org/10.1128/AEM.69.3.1532-1541.2003.

(9)

Sørensen, S. R.; Rasmussen, J.; Jacobsen, C. S.; Jacobsen, O. S.; Juhler, R. K.; Aamand, J. Elucidating the key member of a linuron-mineralizing bacterial community by PCR and reverse transcription-PCR denaturing gradient gel electrophoresis $16 \mathrm{~S}$ rRNA gene fingerprinting and cultivation. Appl. Environ. Microbiol. 2005, 71 (7), 4144-4148. https://doi.org/10.1128/AEM.71.7.4144-4148.2005.

(10) Breugelmans, P.; D’Huys, P. J.; De Mot, R.; Springael, D. Characterization of novel linuron-mineralizing bacterial consortia enriched from long-term linuron-treated agricultural soils. FEMS Microbiol. Ecol. 2007, 62 (3), 374-385. https://doi.org/10.1111/j.1574-6941.2007.00391.x.

(11) Satsuma, K. Mineralisation of the herbicide linuron by Variovorax sp. Strain RA8 isolated from Japanese river sediment using an ecosystem model (microcosm). Pest Manag. Sci. 2010, 66 (8), 847-852. https://doi.org/10.1002/ps.1951.

(12) Bers, K.; Leroy, B.; Breugelmans, P.; Albers, P.; Lavigne, R.; Sørensen, S. R.; Aamand, J.; Mot, R. De; Wattiez, R.; Springael, D. A novel hydrolase identified by genomic-proteomic analysis of phenylurea herbicide mineralization by Variovorax sp. strain SRS16. Appl. Environ. Microbiol. 2011, 77 (24), 8754-8764. https://doi.org/10.1128/AEM.06162-11.

(13) Bers, K.; Batisson, I.; Proost, P.; Wattiez, R.; De Mot, R.; Springael, D. HylA, an alternative hydrolase for initiation of catabolism of the phenylurea herbicide linuron in Variovorax sp. strains. Appl. Environ. Microbiol. 2013, 79 (17), 5258-5263. https://doi.org/10.1128/AEM.01478-13.

(14) Dealtry, S.; Nour, E. H.; Holmsgaard, P. N.; Ding, G. C.; Weichelt, V.; Dunon, V.; Heuer, H.; Hansen, L. H.; 
Sørensen, S. J.; Springael, D.; et al. Exploring the complex response to linuron of bacterial communities from biopurification systems by means of cultivation-independent methods. FEMS Microbiol. Ecol. 2016, 92 (2), 1-12. https://doi.org/10.1093/femsec/fiv157.

550

(15)
Albers, P.; Lood, C.; Özturk, B.; Horemans, B.; Lavigne, R.; van Noort, V.; De Mot, R.; Marchal, K.; SanchezRodriguez, A.; Springael, D. Catabolic task division between two interchangeable near-isogenic subpopulations co-existing in a herbicide-degrading bacterial consortium: Consequences for the interspecies consortium metabolic model. Environ. Microbiol. 2017, 20, 85-96.

https://doi.org/10.1111/1462-2920.13994.

Bers, K.; Sniegowski, K.; Albers, P.; Breugelmans, P.; Hendrickx, L.; De Mot, R.; Springael, D. A molecular toolbox to estimate the number and diversity of Variovorax in the environment: Application in soils treated with the phenylurea herbicide linuron. FEMS Microbiol. Ecol. 2011, 76 (1), 14-25. https://doi.org/10.1111/j.1574-6941.2010.01028.x.

Bers, K.; Sniegowski, K.; De Mot, R.; Springael, D. Dynamics of the linuron hydrolase libA gene pool size in response to linuron application and environmental perturbations in agricultural soil and on-farm biopurification systems. Appl. Environ. Microbiol. 2012, 78 (8), 2783-2789. https://doi.org/10.1128/AEM.06991-11.

Bers, K.; De Mot, R.; Springael, D. In situ response of the linuron degradation potential to linuron application in an Agricultural field. FEMS Microbiol. Ecol. 2013, 85 (3), 403-416. https://doi.org/10.1111/1574-6941.12129.

Horemans, B.; Bers, K.; Romero, E. R.; Juan, E. P.; Dunon, V.; De Mot, R.; Springael, D. Functional redundancy of linuron degradation in microbial communities in agricultural soil and biopurification systems. Appl. Environ. Microbiol. 2016, 82 (9), 2843-2853. https://doi.org/10.1128/AEM.04018-15.

Nour, E. H.; Elsayed, T. R.; Springael, D.; Smalla, K. Comparable dynamics of linuron catabolic genes and IncP-1 plasmids in biopurification Systems (BPSs) as a response to linuron spiking. Appl. Microbiol. Biotechnol. 2017, 101 (11), 4815-4825. https://doi.org/10.1007/s00253-017-8135-6. 
$572 \quad$ (21) Uhlik, O.; Leewis, M. C.; Strejcek, M.; Musilova, L.; Mackova, M.; Leigh, M. B.; Macek, T. Stable isotope

573

574

575

576

577

578

579

580

581

582

583

584

585

586

587

588

589

590

591

592

593

594

595 probing in the metagenomics era: A bridge towards improved bioremediation. Biotechnol. Adv. 2013, 31 (2), 154-165. https://doi.org/10.1016/j.biotechadv.2012.09.003.

(22) Chen, Y.; Murrell, J. C. When metagenomics meets stable-isotope probing: Progress and perspectives. Trends Microbiol. 2010, 18 (4), 157-163. https://doi.org/10.1016/j.tim.2010.02.002.

(23) Jiang, B.; Jin, N.; Xing, Y.; Su, Y.; Zhang, D. Unraveling uncultivable pesticide degraders via stable isotope probing ( SIP ). Crit. Rev. Biotechnol. 2018, 38 (7), 1025-1048.

https://doi.org/10.1080/07388551.2018.1427697.

(24) Koltai, E.; Kling, F.; Rutkai, G. Pesticides labelled with 14C. II. synthesis of propiconazole labelled in three different positions. J. Label. Compd. Radiopharm. 1995, 36 (9), 903-908.

https://doi.org/10.1002/jlcr.2580360912.

(25) Sniegowski, K.; Bers, K.; Van Goetem, K.; Ryckeboer, J.; Jaeken, P.; Spanoghe, P.; Springael, D. Improvement of pesticide mineralization in on-farm biopurification systems by bioaugmentation with pesticide-primed soil. FEMS Microbiol. Ecol. 2011, 76 (1), 64-73. https://doi.org/10.1111/j.1574-6941.2010.01031.x.

(26) Sørensen, S. R.; Aamand, J. Rapid mineralisation of the herbicide isoproturon in soil from a previously treated danish agricultural field. Pest Manag. Sci. 2003, 59 (10), 1118-1124.

https://doi.org/10.1002/ps.739.

(27) Sniegowski, K.; Bers, K.; Ryckeboer, J.; Jaeken, P.; Spanoghe, P.; Springael, D. Robust linuron degradation in on-farm biopurification systems exposed to sequential environmental changes. Appl. Environ. Microbiol. 2011, 77 (18), 6614-6621. https://doi.org/10.1128/AEM.05108-11.

(28) Zhou, J.; Bruns, M. A.; Tiedje, J. M. DNA recovery from soils of diverse composition. Appl. Environ. Microbiol. 1996, 62 (2), 316-322.

Neumann, D.; Heuer, A.; Hemkemeyer, M.; Martens, R.; Tebbe, C. C. Importance of soil organic matter for the diversity of microorganisms involved in the degradation of organic pollutants. ISME J. 2014, 8 (6), 
1289-1300. https://doi.org/10.1038/ismej.2013.233.

(30) Buckley, D. H.; Huangyutitham, V.; Hsu, S. F.; Nelson, T. A. Stable isotope probing with 15N2 reveals novel noncultivated diazotrophs in soil. Appl. Environ. Microbiol. 2007, 73 (10), 3196-3204. https://doi.org/10.1128/AEM.02610-06.

(31) Horemans, B.; Vandermaesen, J.; Vanhaecke, L.; Smolders, E.; Springael, D. Variovorax sp.-mediated biodegradation of the phenyl urea herbicide linuron at micropollutant concentrations and effects of natural dissolved organic matter as supplementary carbon source. Appl. Microbiol. Biotechnol. 2013, 97 (22), 9837-9846. https://doi.org/10.1007/s00253-013-4690-7.

(32) Larsen, M. H.; Biermann, K.; Tandberg, S.; Hsu, T.; Jacobs William R., J. Genetic manipulation of Mycobacterium Tuberculosis. Curr. Protoc. Microbiol. 2007, 6 (1), 10A.2.1-10A.2.21. https://doi.org/10.1002/9780471729259.mc10a02s6.

(33) El Fantroussi, S.; Verschuere, L.; Verstraete, W.; Top, E. M. Effect of phenylurea herbicides on soil microbial communities estimated by analysis of 16S rRNA gene fingerprints and community-level physiological profiles. Appl. Environ. Microbiol. 1999, 65 (3), 982-988.

(34) Klindworth, A.; Pruesse, E.; Schweer, T.; Peplies, J.; Quast, C.; Horn, M.; Glöckner, F. O. Evaluation of general 16S ribosomal RNA gene PCR primers for classical and next-generation sequencing-based diversity studies. Nucleic Acids Res. 2013, 41 (1), 1-11. https://doi.org/10.1093/nar/gks808.

(35) Moreels, D.; Bastiaens, L.; Ollevier, F.; Merckx, R.; Diels, L.; Springael, D. Evaluation of the intrinsic methyl tert-butyl ether (MTBE) biodegradation potential of hydrocarbon contaminated subsurface soils in batch microcosm systems. FEMS Microbiol. Ecol. 2004, 49 (1), 121-128. https://doi.org/10.1016/j.femsec.2004.02.016.

(36) Lemoine, L.; Verbeke, M.; Springael, D.; Bernaerts, K.; Springael, D. Impact of the inoculum composition on the structure of the total and active community and Its performance in identically operated anaerobic reactors. Appl. Microbiol. Biotechnol. 2019. https://doi.org/10.1007/s00253-019-10041-8. 
620

621

622

623

624

625

626

627

628

629

630

631

632

633

634

635

636

637

638

639

640

641

642

643

(37) Quast, C.; Pruesse, E.; Yilmaz, P.; Gerken, J.; Schweer, T.; Yarza, P.; Peplies, J.; Glöckner, F. O. The SILVA ribosomal RNA gene database project: Improved data processing and web-based tools. Nucleic Acids Res. 2013, 41 (D1), 590-596. https://doi.org/10.1093/nar/gks1219.

(38) Yilmaz, P.; Parfrey, L. W.; Yarza, P.; Gerken, J.; Pruesse, E.; Quast, C.; Schweer, T.; Peplies, J.; Ludwig, W.; Glöckner, F. O. The SILVA and "all-species living tree project (LTP)" taxonomic frameworks. Nucleic Acids Res. 2014, 42 (D1), 643-648. https://doi.org/10.1093/nar/gkt1209.

(39) Field, D.; Tiwari, B.; Booth, T.; Houten, S.; Swan, D.; Bertrand, N.; Thurston, M. Open software for biologists: From famine to feast. Nat. Biotechnol. 2006, 24 (7), 801-803. https://doi.org/10.1038/nbt0706801.

(40) Morgulis, A.; Coulouris, G.; Raytselis, Y.; Madden, T. L.; Agarwala, R.; Schäffer, A. A. Database indexing for production MegaBLAST searches. Bioinformatics 2008, 24 (16), 1757-1764.

https://doi.org/10.1093/bioinformatics/btn322.

(41) Edgar, R. C. MUSCLE: Multiple sequence alignment with high accuracy and high throughput. Nucleic Acids Res. 2004, 32 (5), 1792-1797. https://doi.org/10.1093/nar/gkh340.

(42) Stamatakis, A. RAxML Version 8: A tool for phylogenetic analysis and post-analysis of large Phylogenies. Bioinformatics 2014, 30 (9), 1312-1313. https://doi.org/10.1093/bioinformatics/btu033.

(43) Johnsen, A. R.; Binning, P. J.; Aamand, J.; Badawi, N.; Rosenbom, A. E. The Gompertz function can coherently describe microbial mineralization of growth-sustaining pesticides. Environ. Sci. Technol. 2013, 47 (15), 8508-8514. https://doi.org/10.1021/es400861v.

(44) Sniegowski, K.; Mertens, J.; Diels, J.; Smolders, E.; Springael, D. Inverse modeling of pesticide degradation and pesticide-degrading population size dynamics in a bioremediation system: Parameterizing the Monod model. Chemosphere 2009, 75 (6), 726-731. https://doi.org/10.1016/j.chemosphere.2009.01.050.

(45) Turnbull, G. A.; Ousley, M.; Walker, A.; Shaw, E.; Morgan, J. A. W. Degradation of substituted phenylurea herbicides by Arthrobacter Globiformis Strain D47 and characterization of a plasmid-associated hydrolase 
gene, puhA. Appl. Environ. Microbiol. 2001, 67 (5), 2270-2275. https://doi.org/10.1128/AEM.67.5.22702275.2001

646

647

648

(46) Khurana, J. L. L.; Jackson, C. J. J.; Scott, C.; Pandey, G.; Horne, I.; Russell, R. J. J.; Herlt, A.; Easton, C. J. J.; Oakeshott, J. G. G. Characterization of the phenylurea hydrolases A and B: Founding members of a novel amidohydrolase subgroup. Biochem. J. 2009, 418 (2), 431 LP - 441. https://doi.org/10.1042/BJ20081488.

(47) Zhang, L.; Hang, P.; Hu, Q.; Chen, X.; Zhou, X.; Chen, K.; Jiang, J. Degradation of phenylurea herbicides by a novel bacterial consortium containing synergistically catabolic species and functionally complementary hydrolases. J. Agric. Food Chem. 2018, 66, 12479-12489. https://doi.org/10.1021/acs.jafc.8b03703.

(48) Sul, W. J.; Park, J.; Quensen, J. F.; Rodrigues, J. L. M.; Seliger, L.; Tsoi, T. V.; Zylstra, G. J.; Tiedje, J. M. DNAstable isotope probing integrated with metagenomics for retrieval of biphenyl dioxygenase genes from polychlorinated biphenyl-contaminated river sediment. Appl. Environ. Microbiol. 2009, 75 (17), 5501-5506. https://doi.org/10.1128/AEM.00121-09.

(49) Xie, S.; Sun, W.; Luo, C.; Cupples, A. M. Stable isotope probing Identifies novel m-Xylene degraders in soil microcosms from contaminated and uncontaminated sites. Water. Air. Soil Pollut. 2010, 212 (1-4), 113122. https://doi.org/10.1007/s11270-010-0326-z.

(50) Sun, H.; Narihiro, T.; Ma, X.; Zhang, X.; Ren, H.; Ye, L. Diverse aromatic-degrading cacteria present in a highly enriched autotrophic nitrifying sludge. Sci. Total Environ. 2019, 666, 245-251. https://doi.org/10.1016/j.scitotenv.2019.02.172.

(51) Cupples, A. M.; Sims, G. K. Identification of in situ 2,4-dichlorophenoxyacetic acid-degrading soil microorganisms using DNA-stable isotope probing. Soil Biol. Biochem. 2007, 39 (1), 232-238. https://doi.org/10.1016/j.soilbio.2006.07.011.

(52) Zhu, F.; Zhu, C.; Doyle, E.; Liu, H.; Zhou, D.; Gao, J. Fate of di ( 2 ethylhexyl ) phthalate in different soils and associated bacterial community changes. Sci. Total Environ. 2018, 637-638, 460-469. https://doi.org/10.1016/j.scitotenv.2018.05.055. 
668

669

670

671

672

673

674

675

676

677

678

679

680

681

(53) Heulin, T.; Barakat, M.; Christen, R.; Lesourd, M.; Sutra, L.; De Luca, G.; Achouak, W. Ramlibacter tataouinensis gen. nov., sp. nov., and Ramlibacter henchirensis sp. nov., cyst-producing bacteria isolated from subdesert soil in Tunisia. Int. J. Syst. Evol. Microbiol. 2003, 53 (2), 589-594.

(54) Wang, L.; An, D.-S.; Kim, S.-G.; Jin, F.-X.; Kim, S.-C.; Lee, S.-T.; Im, W.-T. Ramlibacter ginsenosidimutans sp. nov ., with ginsenoside-converting activity. J. Microbiol. Biotechnol. 2012, 22, 311-315.

(55) Lee, H. J.; Lee, S. H.; Lee, S.; Lee, J. S.; Kim, Y.; Kim, S.; Jeon, C. O. Ramlibacter solisilvae sp . nov ., isolated from forest soil , and emended description of the genus Ramlibacter. Int. J. Syst. Evol. Microbiol. 2014, 64 (May), 1317-1322. https://doi.org/10.1099/ijs.0.058396-0.

(56) Lee, D.; Cha, C. Ramlibacter alkalitolerans Sp. Nov ., alkali-tolerant bacterium isolated from soil of Ginseng. Int. J. Syst. Evol. Microbiol. 2017, 67 (May), 4619-4623. https://doi.org/10.1099/ijsem.0.002342.

(57) Yan, Z.; Trinh, H.; Moya, G.; Lin, P.; Li, C.; Kook, M.; Yi, T. Ramlibacter rhizophilus sp . nov ., isolated from rhizosphere soil of national flower Mugunghwa from South Korea. Int. J. Syst. Evol. Microbiol. 2017, 67 (October), 3773-3777. https://doi.org/10.1099/ijsem.0.002191.

(58) Chaudhary, D. K.; Kim, J. Ramlibacter monticola Sp . nov ., isolated from forest soil. Int. J. Syst. Evol. Microbiol. 2017, 67 (November), 4468-4474. https://doi.org/10.1099/ijsem.0.002314.

(59) Props, R.; Monsieurs, P.; Vandamme, P.; Leys, N.; Denef, V. J.; Boon, N. Gene expansion and positive selection as bacterial adaptations to oligotrophic conditions. mSphere 2019, 4 (1), e00011-19. https://doi.org/10.1128/mSphereDirect.00011-19.

(60) Geyer, K. M.; Kyker-Snowman, E.; Grandy, A. S.; Frey, S. D. Microbial carbon use efficiency: accounting for population, community, and ecosystem-scale controls over the fate of metabolized organic matter. Biogeochemistry 2016, 127 (2-3), 173-188. https://doi.org/10.1007/s10533-016-0191-y.

Król, J. E.; Penrod, J. T.; McCaslin, H.; Rogers, L. M.; Yano, H.; Stancik, A. D.; Dejonghe, W.; Brown, C. J.; Parales, R. E.; Wuertz, S.; et al. Role of IncP-1ß plasmids pWDL7::Rfp and pNB8c in chloroaniline catabolism as determined by genomic and functional analyses. Appl. Environ. Microbiol. 2012, 78 (3), 828-838. 

https://doi.org/10.1128/AEM.07480-11.

693

(62) Shintani, M.; Takahashi, Y.; Yamane, H.; Nojiri, H. The behavior and significance of degradative plasmids 694 belonging to Inc groups in Pseudomonas within natural environments and microcosms. Microbes Env. 2010, 25 (4), 253-265. https://doi.org/10.1264/jsme2.ME10155.

696

697 